UDC 645.46 .3

I. Shevchenko,

PhD in Economics, Associate Professor of the Department of Accounting and Business Consulting, Kharkiv National University of Economics named after Semen Kuznets

ORCID ID: 0000-0001-8188-3551

DOI: $10.32702 / 2306-6806.2021 .12 .78$

\title{
STATE FINANCIAL AUDIT OF INVESTMENT PROJECTS AS AN ELEMENT OF PUBLIC FINANCIAL CONTROL
}

\author{
I. О. Шевченко, \\ к. е. н., доцент кафедри обліку і бізнес-консалтингу, \\ Харківський національний економічний університет імені Семена Кузнеця
}

\section{АЕРЖАВНИЙ ФІНАНСОВИЙ АУАИТ ІНВЕСТИЦІЙНИХ ПРОЄКТІВ ЯК ЕАЕМЕНТ АЕРЖАВНОГО ФІНАНСОВОГО КОНТРОАЮ}

The research object is the process of state financial audit of investment projects. The article is devoted to scientific substantiation of theoretical positions and improvement of organizational and technological stages of financial audit of investment projects of domestic enterprises. An analysis of the stages of formation and development of the state audit in Ukraine, which in the author's opinion can be nominally divided into five periods.

The author believes that one of the most problematic areas is the second period of establishment and development of the state audit in Ukraine in general and state financial audit of investment projects in particular.

In the course of the research the system of general scientific and special research methods was used: logical summarization - to summarize theoretical models, to reveal substantive and typological characteristics, structural-logical analysis - to identify the interconnections between the main concepts of the study and its stages, graph theory - to picture the interrelation of the concept's thesaurus; system approach - to explain the content; graphical method - to construct theoretical and practical research positions schematically.

Analyzed the current theoretical basis of the state financial audit in general and the state financial audit of investment projects in particular. It was found that it is characterized by a certain confusion and residual unambiguity of the key understandings. In addition, there are systemic problems related to the establishment of the state audit system and determining the place of the state financial audit of investment projects in it. To disclose these issues the author proposed to disclose the essence of the concept of "state financial audit of investment programs" by summarizing the modern definitions of this concept and strengthening approaches to its definition. Through a thorough analysis of theoretical foundations of the state financial audit of investment projects, the author tries to give his own definition of the notion of state financial audit of investment projects. The novelty of the proposed definition lies in taking into account such features as the expected result of the expected ou tcome aimed at achieving the goal of the investment project and identifying reserves for increasing its effectiveness. The author also proposes an indicative model of structural elements of the state financial audit of investment projects.

Об'єктомдослідження є процес,державного фінансового аудиту інвестиційних проєктів. Статтю приСвячено науковому обгрунтуванню теоретичних положень та вдосконаленню організаційних і технологічних етапів фінансового аудиту інвестиційних проєктів вітчизняних підприємств. Проведено аналіз етапів становлення та розвитку державного аудиту в Україні, які, на думкУ автора, можна умовно поділити на п'ять періодів.

Одним із набільш проблемних місць, на думку автора, є п'ятий період становлення та розвитку державного аудиту в Украйні взагалі та державного фінансового аудиту інвестиційних проєктів зокрема. 
У ході дослідження використано систему загальнонаукових і спеціальних методів дослідження: Аогічного Узагальнення - АЯя Узагальнення теоретичних моделей, розкриття сутнісних і типологічних характеристик, структурно-логічного аналізу - Аля визначення взаємозв'язків між основними поняттями дослідження та його етапами, теорія графів - для зображення взаємозв'язку тезауруса поняття, системний підхіА - Аля обгрунтування змісту, графічний метод - Аля схематичної побудови теоретичних практичних положень дослідження.

Проаналізовано існуючу теоретичну базудержавного фінансового аудиту загалом тадержаного фінанСового аудиту інвестиційних проєктів зокрема. Визначено, що вона характеризується певною плутаниною та остаточною невизначеністю кАючових Понять. Крім того, існують Проблемні Питання Системного характеру, що стосуються побудови системи державного аудиту та визначення місця в ній державного фінансового аудиту інвестиційних проєктів. АЯя розкриття, даних питань автором запропоновано розкрити сутнісне розуміння поняття "державний фінансовий аудит інвестиційних програм" шляхом Узагальнення сучасних визначення даного поняття та виокремлення підходів до його визначення. Завдяки ретельному аналізу теоретичних засад державного фінансового аудиту інвестиційних проєктів, автор робить спробу надати власне визначення поняття державний фінансовий аудит інвестиційних проєктів. Новизна запропонованого визначення полягає у врахуванні такої ознаки, як багатоваріантність очікуваного результату спрямованого на досягнення мети інвестиційного проєктУ та виявлення резервів підвищення його результативності. Автором також пропонується змістовна модель структурних елементів державного фінансового аудиту інвестиційних проєктів.

Key words: audit, control, state financial control, state financial audit, audit of state finances, investment projects, state financial audit of investment projects, investment project.

Ключові слова: аудит, контроль, державний фінансовий контроль, державний фінансовий аудит, аудит державних фінансів, інвестичіині проєкти, державний фінансовии аудит інвестичійних проєктів, інвестичійний проєкт.

\section{INTRODUCTION}

Creating an effective system of public financial management as a basis for the development of all areas of public policy requires timely and effective control, which would ensure openness, transparency and accountability of public authorities to society. That is why the current stage of reforming the country's economy objectively requires the introduction of a new form of public financial control public financial audit of investment projects.

The introduction of public financial audit of investment projects in the system of public financial control is due to the need to control not only the rationality and purposeful use of public funds, but also to assess their effectiveness, efficiency and social significance. In addition, the state financial audit of investment projects provides a comprehensive study of the causes, both real and potential, of inefficient spending of budget funds and provides justification and development of appropriate recommendations and proposals for both objects of control, within which control measures were performed, and and its subjects.

\section{OBJECT OF RESEARCH \\ AND ITS TECHNOLOGICAL AUDIT}

The object of research is the process of state financial audit of investment projects. The need to develop a public financial audit of investment projects is also exacerbated by the presence of a significant number of investment projects and the amount of their funding. This, in turn, can lead to fraud and theft of budget funds and state property. And although the state financial audit of investment projects is mostly a new phenomenon in the theory and practice of public financial control of Ukraine, it is one of the levers to increase financial discipline in the use of budget funds and reduce budgetary and financial abuses and crimes. Its development, on the one hand, will increase the efficiency of budget spending, and on the other - will bring the conditions and procedure for its implementation to international requirements.

\section{THE PURPOSE AND OBJECTIVES OF THE STUDY}

The purpose of the article is the theoretical generalization and development of scientifically sound practical recommendations aimed at improving the theoretical foundations of public financial audit of investment projects. According to the defined purpose in work the following tasks are set:

1) to reveal the periodization of the formation and development of public audit in Ukraine in general and public financial audit of investment projects in particular;

2) analyze modern definitions of public financial audit of investment projects and comment on them;

3 ) to single out the approaches to the definition of "public financial audit of investment projects;

4) formulate your own definition of the concept of public financial audit of investment projects;

$5)$ construct the semantic model of structural elements of the system of state financial audit of investment projects.

\section{FORMULATION \\ OF THE PROBLEM}

The imperfection of the legal and methodological support for the audit of investment projects leads to the inability to fully ensure proper state financial control over the use of borrowed funds under the investment project and requires government regulation. The problem that is proposed to be solved through state regulation does not affect small businesses. This problem cannot be solved with the help of market mechanisms, as the issue is to ensure effective public financial control over the use of borrowed funds in the investment project and its implementation. One of the most important elements of the development of the national economy in a market economy is a balanced investment policy of the state, which results in the effective operation and progressive development of economic entities. The main purpose of investing is to stimulate the process of expanded reproduction of production, accumulation of capital, providing access to modern 


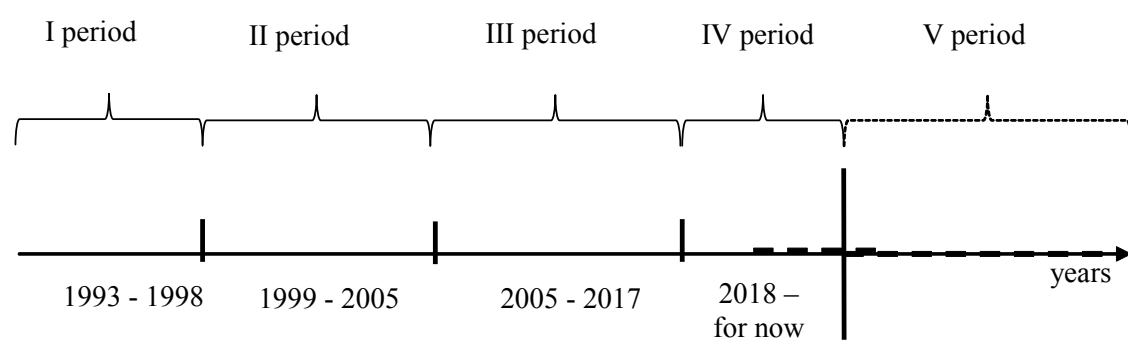

Fig. 1. Periodization of the formation and development of public audit in Ukraine in general and public financial audit of investment projects in particula (built on $1,2,3,5$ )

technologies and management, creating new value and, as a result, promoting dynamic economic change.

Despite significant developments in this area, many issues of theoretical, organizational and methodological nature remain out of the focus of scientists. In particular, further study of organizational and technological aspects of public financial audit at all stages of the life cycle of investment projects, require further development of public financial audit of the effectiveness of investment projects and more.

\section{RESEARCH METHODS}

In the course of the research a system of general scientific and special research methods was used: logical generalization - for generalization of theoretical models, disclosure of essential and typological characteristics, structural-logical analysis - for determination of interrelations between basic concepts of research and its stages, theory of graphs - for representation of interrelations. thesaurus language concept, a systematic approach - to justify the content, a graphical method - for a schematic construction of theoretical and practical provisions of the study.

\section{ANALYSIS OF RECENT RESEARCH}

\section{AND PUBLICATIONS}

The scientific works of such Ukrainian and foreign scientists as G.M. Davydov, T.L. Hrytsai, V.V. Siebert, J.J. Dankiv, L.V. Dikan, K.I. Redchenko, O.A. Petrik, V.V. Shkirenko and others.

\section{PRESENTATION \\ OF THE MAIN RESEARCH MATERIAL}

The formation and development of public financial control in Ukraine is taking into account the rich experience of the European Union, where our country integrates.

The formation of policy in the field of financial control in Ukraine plays an important role in shaping public opinion to ensure public authorities and management of the legality and efficiency of public funds.

Since Ukraine's independence, there have been constant changes in the legislation on the formation of the system of public financial control, the distribution and redistribution of their powers, introduced and abolished various forms of control measures, implemented foreign experience in the practice of bodies responsible for control functions.

The development of public financial audit in both global and national practice is inextricably linked with the formation and development of financial control in the public sector.

Financial control in the basic model of the EU includes: public internal financial control, external audit, protection of the EU's financial interests and the fight against fraud. EU member states and candidate countries are independent in defining control mechanisms for national financial management, establishing appropriate state institutions for control and building national financial control systems that meet the needs and strategic vectors of the state. At the same time, the basic model of financial control, which is defined in the EU, must be built by a country that has expressed its desire to join the European Union and operate in accordance with EU rules.

Thus, the stages of formation and development of state audit in Ukraine can be divided into five periods (Fig. 1).

It should be noted that in Ukraine the beginning of the formation and development of public audit was laid in 1996 with the establishment of the Accounting Chamber of Ukraine, which became a permanent body of external control of public finances.

According to the author, it is necessary to pay special attention to the fifth period of formation and development of public audit in Ukraine in general and public financial audit of investment projects in particular (Fig. 1).

Thus, the fifth period is the beginning of the development of public financial audit of investment projects. This period continues to this day. At the same time, it should be noted that the changes that have taken place in the control of public finances in recent years are due to Ukraine's European integration policy and the main requirements of the European community. On September 12, 2018, the Cabinet of Ministers of Ukraine approved Resolution № 740 On approval of the Procedure for conducting investment projects by the State Audit Service, its interregional territorial bodies of state financial audit [1]. The resolution defines the mechanism for conducting investment projects by the State Audit Office, its interregional territorial bodies of state financial audit.

The existing theoretical basis of the state financial audit in general and the state financial audit of investment projects in particular is characterized by a certain confusion and final uncertainty of key concepts. In addition, there are problematic issues of a systemic nature related to the construction of the state audit system and determining the place of state financial audit of investment projects. To disclose these issues, the author proposes to reveal the essential understanding of the concept of "public financial audit of investment programs." The analysis of sources allowed the author to generalize modern definitions of this concept (Table 1$)$.

As can be seen from Table 1 , there are many different views on the interpretation of this concept, but according to the author, none of them fully reveals the essential understanding of the definition of this definition. Therefore, the author considers it appropriate to disclose approaches to the definition (Fig. 2).

Analyzing table 1 and fig. 2 , it should be noted that the definitions enshrined in law and modern authors are quite general and in no way distinguish the features of the state financial audit of investment projects.

Due to a careful analysis of the theoretical foundations of public financial audit of investment projects, we can conclude that today there is no single view on the definition of this concept. Therefore, the author tries to provide his own definition of public financial audit of investment projects - a dynamic form of public financial audit that involves a systematic study of legality, cost-effectiveness and efficiency of investment projects, reliability and rationality of costs to achieve the investment project and identify reserves to improve its effectiveness. The novelty of the proposed definition is to take into account such a feature as the diversity of the expected result aimed at achieving the goal of the investment project and identifying reserves to improve its effectiveness.

Among the tasks of the state financial audit of investment projects, the author proposes to identify the following:

1. Checking the correctness of the attribution of state assets to investments, determining their value.

2. Differentiation in the accounting of investments on the relevant grounds, including projects. 
Table 1. Definition of the state financial audit of investment projects

\begin{tabular}{|c|c|c|}
\hline Source & Definition of the concept & Comment \\
\hline Decree & $\begin{array}{l}\text { Type of state financial audit, aimed at analyzing and } \\
\text { verifying the legality and effectiveness of investment } \\
\text { projects by audited entities, which is carried out on the } \\
\text { basis of state and local investment, state support, state and / } \\
\text { or local guarantees, and the state of performance, } \\
\text { management and use of investments (funds) }\end{array}$ & $\begin{array}{l}\text { According to the author, } \\
\text { the normatively fixed } \\
\text { concept narrows the } \\
\text { purpose of the state } \\
\text { financial audit of } \\
\text { investment projects }\end{array}$ \\
\hline G. Davidov & $\begin{array}{l}\text { The audit of investment projects is entrusted with the } \\
\text { functions of preventive control and diagnosis of probable } \\
\text { errors at the stage of investment planning. As their } \\
\text { implementation requires the involvement of a significant } \\
\text { amount of financial resources with a high level of risk, the } \\
\text { audit should help to choose the most optimal investment } \\
\text { parameters, thereby reducing the risk of financial losses to } \\
\text { the investor. Therefore, each project involves finding the } \\
\text { best option among the many possible }\end{array}$ & $\begin{array}{l}\text { Narrows the essence of } \\
\text { the audit of investment } \\
\text { projects only to the audit } \\
\text { at the pre-investment } \\
\text { stage }\end{array}$ \\
\hline T. Gritsay & $\begin{array}{l}\text { The audit of the investment project helps to answer the } \\
\text { following questions of the strategic plan of the project: } \\
\text { what is the minimum value and what return on invested } \\
\text { capital from the project is acceptable for the company; what } \\
\text { is the maximum allowable amount of investment; optimal } \\
\text { term of project implementation; what will be the company's } \\
\text { image from the implementation of a particular project; what } \\
\text { risk can be considered high; projects of what type and scale } \\
\text { correspond to organizational and financial possibilities of } \\
\text { the company }\end{array}$ & Audit tasks are shifted \\
\hline K.I. Redchenko & $\begin{array}{l}\text { The audit of investment projects should perform the } \\
\text { functions of preventive control and preliminary diagnosis of } \\
\text { probable errors in investment planning and deviations from } \\
\text { the optimal parameters of the project }\end{array}$ & $\begin{array}{l}\text { Narrows the essence of } \\
\text { the audit of investment } \\
\text { projects }\end{array}$ \\
\hline $\begin{array}{l}\text { O.A. Petrik, } \\
\text { V.V. Shkirenko }\end{array}$ & $\begin{array}{l}\text { The process of verifying and generating information } \\
\text { support for the purpose meeting the needs of management, } \\
\text { analysis of economic policy of the enterprise, certain } \\
\text { management mechanisms and procedures adopted by the } \\
\text { management of the organization in order to maintain high } \\
\text { level of efficiency of realization of investment strategy of } \\
\text { the business entity, management investment risks and } \\
\text { achieving the desired economic (social) effect }\end{array}$ & $\begin{array}{l}\text { Narrows the purpose and } \\
\text { objectives of the state } \\
\text { financial audit of } \\
\text { investment projects }\end{array}$ \\
\hline
\end{tabular}

3. Checking the correctness of the organization and maintenance of records related to the implementation of investment projects.

4. Confirmation of the correctness of the documentation of public expenditures.

5. Cost verification.

6. Verification of the procedure for monitoring public procurement and control of public procurement for compliance with legal requirements, requirements of the investor or donor of investment resources.

7. Confirmation of legality, completeness and reliability of reflection of operations on realization of investment projects on accounts of accounting and in the financial reporting.

Analysis of special literature and economic and political conditions of management in Ukraine, according to the author, the most thorough for the state financial audit of investment projects are the following:

- the principle of independence, which provides for financial, functional and organizational independence of the subject of control;

- the principle of legality determines the compliance of regulatory authorities with regulatory documents in the field of public financial audit of investment projects;

- the principle of efficiency, which involves the assessment of costs associated with the implementation of control measures;

- the principle of responsibility, which includes the responsibility of officials exercising control powers; responsibility of controlled entities; the responsibility of persons who are responsible for the implementation of tasks to implement the recommendations of the state financial audit of investment projects;

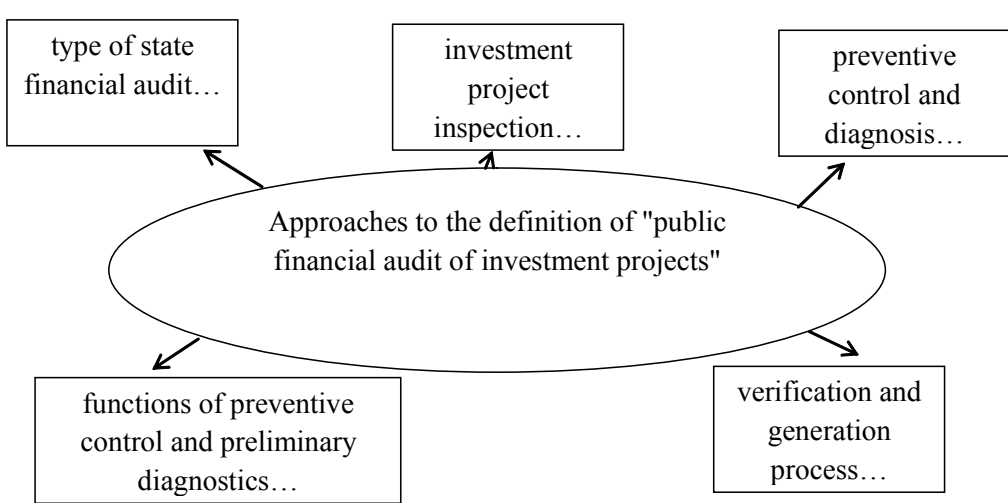

Fig. 2. Approaches to the definition of "public financial audit of investment projects" (selected and summarized on the basis of table 1)

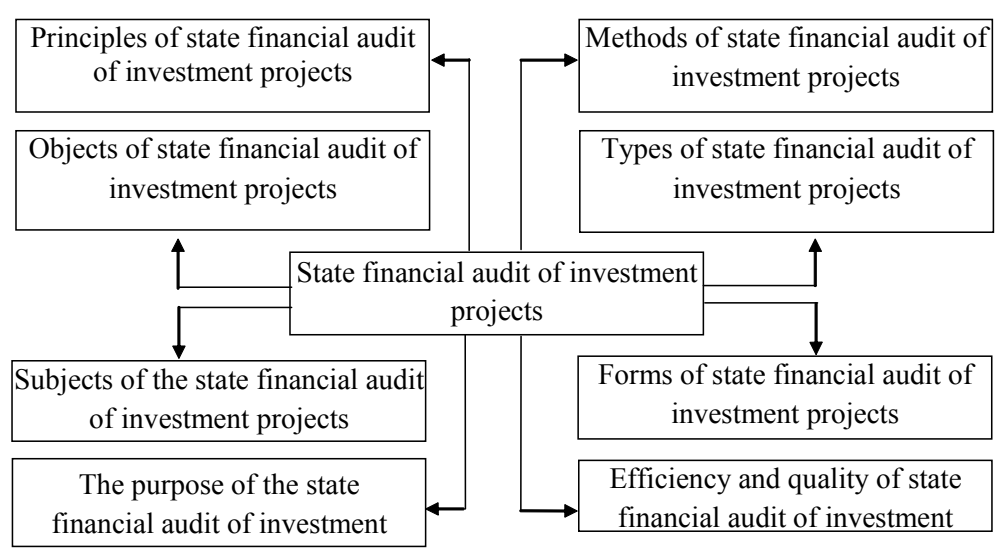

Fig. 3. Semantic model of structural elements of the system of state financial audit of investment projects 
- the principle of planning, which provides for the development of control plans for the upcoming reporting period;

- the principle of professionalism presupposes that the subjects of the state financial audit have investment projects of appropriate competencies;

- the principle of publicity, which allows access to various control bodies and the general public to the results of control measures;

- the principle of objectivity, determines the lack of subjective assessments in the activities of public financial audit of investment projects.

In view of the above, the author proposes the following substantive model of structural elements of the state financial audit of investment projects. (Fig. 3).

Analyzing fig. 3 it is worth noting that the state financial audit of investment projects should be considered in terms of system-process approach, when on the one hand, the object of study is presented as part of the control elements.

As mentioned above, domestic experts suggest that several methods of auditing investment projects have been developed taking into account the specifics of a particular industry, but there is no generalized methodology. Studying the practice of auditing investment projects in foreign countries, we concluded that many companies use methodological approaches developed by large audit companies, in particular Deloitte, PwC, KPMG.

It should be noted that the audit procedures at each stage of the independent audit of investment projects may be supplemented, depending on the specifics of the project, as well as the results of previous audits (if any).

One of the most important stages of the audit should be considered the preparatory, which develops the audit program, as the completeness of coverage of issues in the audit process largely determines the usefulness of the information obtained from the audit, for the investor. The list of issues that are included in the audit program depends on the specifics of the investment project and the task set by the project customer.

\section{CONCLUSIONS FROM THIS STUDY AND FURTHER PROSPECTS IN THIS DIRECTION}

Thus, in international practice, the methodology of public financial audit of investment projects is provided by a quality level of standards that define institutional norms for the organization and operation of public financial audit of investment projects, audit quality assurance, fundamental principles, general and special methods. Today, ISSAI is an important tool for quality control over the principles of economy, efficiency, effectiveness and transparency in the process of state resource management, which unifies the approaches, principles of auditing and directions of its development based on the implementation of best practices.

Since 2016, the State Audit Service has launched a number of strategic tasks and Government documents to develop public financial control and audit, including modernization of regulatory and methodological support for implemented types of public financial audit and developed a legal framework for new types of audits based on international auditing standards.

The process of transformation of audit audit is taking place with proper scientific and practical justification, taking into account the principles of ISSAI, is not spontaneous, but mutually agreed, conceptual, comprehensive and systematic approach, taking into account national legislation, other regulations governing the powers of public authorities. financial control, directions of their development and priorities of development of the system of state financial control at the state, regional and local level.

\section{Мітература:}

1. Грицай Т.А. Аналіз та аудит інвестиційних проєктів: дис. канд. екон. наук: 08.00.09. Київ, 2012. 192 с.

2. Аавидов Г.М. Аудит: навч. посіб. 2-е вид., перероб. та доп.. Житомир: Рута, 2002. - 672 с.

3. Аікань М.В., Шевченко І.О. Розвиток типології державного аудиту в міжнародній та національній практиці. Економіка розвитку. 2016. № 3 (79). С. 34-40. URL: http://www.ed.ksue.edu.ua/ER/knt/eu163_79/e163dik.pdf (Аата звернення 23 Серпня 2021).

4. Петрик О.А. Особливості внутрішнього аудиту інвестиційних проєктів. Вісник Національного університету " $\Lambda$ ьвівська політехніка". Менеджмент та підприємництво в Україні: етапи становлення і проблеми розвитку. 2014. № 797. С. 292-299. URL: http://nbuv.gov.ua/ UJRN/VNULPM_2014_797_42 (Аата звернення 23 СерПня 2021).

5. Сіберт В.В., Ааньків Й.Я. Організація і технологічні етапи незалежного фінансового аудиту інвестиційних проєктів / Облік, аналіз, аудит і оподаткування в умовах глобалізації економіки: Збірник наукових статей випускників з фаху "Облік і оподаткування". Вип. 8 (2018). Ужгород: Видавництво УжННУ "Говерла", 2018. C. $83-89$.

6. Шевченко I.О. Теоретичні засади аудиту як форми фінансового контролю. Молодіжний економічний вісник ХНЕУ ім. С. Кузнеця. 2016. № 11. С. 397-404. URL: http://www.hneu.edu.ua/web/public/moved/hneu/ NAUKA/Naukovi_vudannya/MV/MV_11_2016.pdf (Аата звернення 25 Серпня 2021).

7. Про затвердження Порядку здійснення Аержавною аудиторською службою, їі міжрегіональними територіальними органами державного фінансового аудиту Порядку здійснення інвестиційних проєктів: постанова Кабінету Міністрів України від 12 вересня 2018 р. № 740. URL: https://zakon. rada.gov.ua/laws/show/7402018-\%D0\%BF\#Text (Аата звернення 20 Серпня 2021).

\section{References:}

1. Hrytsaj, T.L. (2012), "Analysis and audit of investment projects", Abstract of Ph.D. dissertation, economic analysis, Kyiv National University of Economics named after V. Hetman, Kyiv, Ukraine.

2. Davydov, H.M. (2002), Audyt [Audit], 2nd ed, Ruta, Zhytomyr, Ukraine.

3. Dikan, L.I. and Shevchenko, I.O. (2016), "The development of a typology of state audit in the international and national practice", Ekonomika rozvytku, vol. 3 (79), pp. 34-40, available at: http:// www.ed.ksue.edu.ua/ER/ knt/eu163_79/e163dik.pdf (Accessed 23 August 2021).

4. Petrik, O.A. and Shkirenko, V.V. (2014), "Features internal audit investment projects", Visnyk Natsional'noho universytetu "L'vivs'ka politekhnika". Menedzhment ta pidpryiemnytstvo v Ukraini: etapy stanovlennia i problemy rozvytku, vol. 797, pp. 292-299, available at: http:/ nbuv.gov.ua/UJRN/VNULPM_2014_797_42 (Accessed 23 August 2021)

5. Sibert, V.V. and Dankiv, J.Y. (2018), "Organization and technological stages of independent financial audit of investment projects", UzhNU "Hoverla", vol. 8, pp. 83-89.

6. Shevchenko, I.O. (2016), "Theoretical principles of audit as a form of financial control", Molodizhnyj ekonomichnyj visnyk KhNEU im. S. Kuznetsia, vol. 11, available at: http://www.hneu.edu.ua/web/public/moved/hneu/ NAUKA/Naukovi_vudannya/MV/MV_11_2016.pdf (Accessed 25 August 2021).

7. Cabinet of Ministers of Ukraine (2018), "Resolution of the Cabinet of Ministers of Ukraine "On approval of the Procedure for conducting investment projects by the State Audit Service, its interregional territorial bodies of state financial audit"", available at: https://zakon.rada.gov.ua/ laws/show/740-2018-\%D0\%BF\#Text (Accessed 20 August 2021).

Стаття надійила до редакиї 24.11.2021 p. 